\title{
Effect of Copper and Lead on Growth and Some Metabolic Activities of Cyanobacterium Spirulina platensis (Nordstedt)
}

\author{
Soad M. Mohy El-Din ${ }^{\#}$ \\ Department of Botany and Microbiology, Faculty of Science, Alexandria \\ University, Alexandria, Egypt.
}

\begin{abstract}
$\mathbf{T}$ ODAY the heavy metal pollution is one of the most important environmental problem, which causes in soil and aquatic environment. Biosorption is an innovative technology that employs biological materials to accumulate heavy metals from waste water through metabolic process or physicochemical pathways of uptake. We studied the metabolic responses of Spirulina platensis to the toxicity of two heavy metals, $\mathrm{Cu}^{2+}$ and $\mathrm{Pb}^{2+}$. The data show that the lower doses of metals had stimulatory effect on biomass of Spirulina platensis, whereas the higher doses were found to be inhibitory depending on the type of the metal. The inhibitory effect of copper upon growth parameters of Spirulina platensis was more pronounced than lead. The total protein content, chlorophyll content, total carbohydrate and the total free amino acids of the tested alga gradually decreased in a manner dependent on the metal concentration in the medium. Biosorption of algal biomass was found to be heavy metal concentrations and $\mathrm{pH}$ dependent, where Spirulina platensis accumulated the amount of $\mathrm{Pb}^{2+}$ more than $\mathrm{Cu}^{2+}$. Concerning the effect of different concentrations of $\mathrm{Cu}^{2+}$ and $\mathrm{Pb}^{2+}$ on photosynthetic $\mathrm{O}_{2}$ evolution, the results showed reduction in the amount of $\mathrm{O}_{2}$ evolved in response to increasing metals concentrations. On the other hand, the effect of the heavy metals on respiration showed that higher metals concentrations were inhibitory to $\mathrm{O}_{2}$ uptake by Spirulina platensis.
\end{abstract}

Keywords: Growth, Pigments, Heavy metals, Spirulina platensis.

\section{Introduction}

Aquatic ecosystems are particularly susceptible to accumulating contaminants. Due to their widespread industrial use, large quantities of metals compound are discharged into freshwater ecosystems and the levels of these have increased substantially world-wide over the last century (Penuelas \& Filella, 2002). Although metal compounds are originating from the bedrock, these chemicals largely enter the eco-environment through industrial and agricultural activities, and then transferred to the food chain (Schutzendubel $\&$ Polle, 2002). Therefore, many scientific reports studied the toxicity of heavy metals, their effects on the environment, their ability to enter the food chain and their threat on the health of human being(Bing et al., 2013).

Metals discharged as solutes or particles are generally non-biodegradable in nature and can produce bio-hazardous effects. They present in the environment with a wide range of oxidation states and coordination numbers, which are related to their toxicity (Murugan \& Harish, 2007)

Copper is an essential micronutrient for numerous physiological processes and for keeping biochemical functions at low concentrations but a toxic metal at high concentrations (Gaetke \& Chow, 2003). The progressive increase of copper in aquatic ecosystems arises from various anthropogenic sources including copper mine drainage, copper- based pesticides, industrial and domestic wastes and antifouling paints (Andrade et al., 2004). Lead uptake by living organism comes from contaminated water, air and soil. Accumulation of lead in mammals influences the nervous system by slowing down neural response. Passage of lead through blood vessels, bone marrow, liver and kidneys leads to

\#Corresponding author email: dr.soad_mohi@hotmail.com

DOI: 10.21608/ejbo.2017.822.1055

C2017 National Information and Documentation Centre (NIDOC) 
disturbance in kidneys and liver functions, damage in reproductive organs, anemia and metabolic disorders (Henick-Kling \& Stoewasnd,1993). Biological materials with sufficiently high metalbinding capacity and selectivity for heavy metals can be used in a full-scale biosorption for the recovery of heavy metals ions from industrial waste streams (Volesky \& Holan, 1995). Algae, bacteria and fungi have proved to be potential metal biosorbents (Volesky, 1994). Different researchers have reported the bioaccumulation of large quantities of heavy metals by different algae under diversely stressed natural condition. Cyanobacteria, a numerous and diverse group of photosynthetic prokaryotes are key contributors to the global photosynthetic productivity. Their response to toxic metal exposure is of great concern due to the fact that bioaccumulation of heavy metals in the aquatic food chain is highly dangerous (Sanita-di-Toppi \& Gabbrrielli,1999). Aquatic plants and microorganisms are able to remove metals from water through processes of biosorption and metabolism dependent bioaccumulation (Wang et al., 1998).

This study aimed to assess the uptake of selected heavy metals, copper and lead by living and nonliving Spirulina platensis and to investigate some metabolic and physiological activitiesin Spirulina platensis induced by these chemical pollutants.

\section{Materials and Methods}

\section{Organism and culture condition}

The blue green microalga Spirulina platensis (Nordstedt) Geitler (Oscillatoiales) was obtained from the Institute of Oceanography and Fisheries in Alexandria (ARE). Alga used for experimental studied was axenic.

Spirulina platensis was cultivated in a liquid medium, which was prepared as described in Zarrouk,which modified by Vonshak (1997). Cultures of algae were grown at $25 \pm 1^{\circ} \mathrm{C}$ in a temperature-controlled room. Illumination was provided with an irradiance of $200 \mu \mathrm{mol} \mathrm{m} \mathrm{m}^{-2} \mathrm{~s}^{-1}$, under a $16 \mathrm{~h} / 8 \mathrm{~h}$ light / dark regime. All cultures were shaken twice daily to prevent cells from clumping. Seven days old cultures were spun down at $4000 \mathrm{~g}$ for $10 \mathrm{~min}$ and the pellets were resuspended in fresh medium in order to use for the metal treatments.

\section{Chemical and analytical methods}

The chemicals were of analytical grade and used without further purification. De-ionized water obtained from a Millipore Milli-Q system was used throughout the experiment. Copper sulphate $\left(\mathrm{CuSO}_{4} \cdot 5 \mathrm{H}_{2} \mathrm{O}\right)$ and Lead nitrate $(\mathrm{Pb}$ $\left(\mathrm{NO}_{3}\right)_{2}$ ) were used as the sources of $\mathrm{Cu}^{2+}$ and $\mathrm{Pb}^{2+}$ respectively. The stock solutions $(1000 \mathrm{mg} / \mathrm{L})$ were prepared and kept in a refrigerator at $4{ }^{\circ} \mathrm{C}$ until use.

\section{Effect of pH on uptake of copper and lead \\ Living biomass}

A standard initial inoculum of the tested alga $5 \mathrm{~mL}$ precultured was inoculated to culture flasks (250 $\mathrm{mL}$ each) that contained $100 \mathrm{~mL}$ of sterile nutrient medium. The culture flasks were supplied with a concentration of Copper and Lead $(1 \mathrm{mg} / \mathrm{L})$ and adjusted $\mathrm{pH}$ values $(8.5,9,9.5,10,10.5,11$ and 11.5). The cultures were incubated for 8 days at temperature $30^{\circ} \mathrm{C}$, then the biomasses were harvested, and assayed metal uptake.

\section{Nonliving biomass}

Samples $(0.25 \mathrm{~g})$ of untreated dried biomass of Spirulina platensis were added to $(250 \mathrm{ml}$ conical flasks containing $100 \mathrm{ml}$ of $1 \mathrm{mg} / \mathrm{L}$ solutions media for either copper or lead in each flask, which adjusted $\mathrm{pH}$ values $(2,5,7,9$ and11). The biomasses were incubated at $30^{\circ} \mathrm{C}$ for $24 \mathrm{~h}$, and then they were harvested to assay metal uptake.

\section{Effect of different heavy metal concentrations Living biomass}

A standard initial inoculum of the tested alga $5 \mathrm{~mL}$ precultured was inoculated to culture flasks (250 mL each) that contained $100 \mathrm{~mL}$ of sterile nutrient medium. The culture flasks were supplied with various concentrations of Copper and Lead $(0,0.5,1$ and $3 \mathrm{mg} / \mathrm{L})$. Then the $\mathrm{pH}$ of each culture was adjusted to the optimum $\mathrm{pH}$ equal to 9.8 (determined from the previous experiment). The percentage of metal uptake was determined.

\section{Nonliving biomass}

Different concentrations of heavy metals $(0.5$, $1,3,5$ and $10 \mathrm{mg} / \mathrm{L})$ were tested at the optimum $\mathrm{pH}$ for each metal. The powdered alga $(0.25 \mathrm{~g})$ were added to the metal solution. The percentage of metal uptake was determined.

A standard initial inoculum of the tested alga $10 \mathrm{~mL}$ precultured was inoculated to culture flasks $(500 \mathrm{~mL}$ each) that contained $200 \mathrm{~mL}$ of sterile nutrient medium. The culture flasks were supplied with various concentrations of Copper and Lead $(0,0.5,1$ and $3 \mathrm{mg} / \mathrm{L})$. Then the $\mathrm{pH}$ 
of each culture was adjusted to the optimum $\mathrm{pH}$ equal to 9.8. At the end of the incubation period ( 8 days) cultures were filtered and washed several times by distilled water, and then were assayed for chlorophyll, protein, carbohydrate and amino acids determinations. Three replicates for each sample and controls were used.

\section{Determination of metal uptake}

For the measuring metal contents, the cultures were centrifuged to harvest the algal mass $(50 \mathrm{~mL})$. The pellet was digested $5 \mathrm{~mL}$ mixture containing $\mathrm{HNO}_{3}(70 \%), \mathrm{H}_{2} \mathrm{O}_{2}(30 \%)$ and deionized water in 1:1:3 ratio (Bates et al.,1982). After digestion the samples were analyzed for metal content with a Perkin-Elmer atomic absorption spectrophotometer.

\section{Determination of dry weight}

A definite volume $(100 \mathrm{~mL})$ of algal suspension was filtered through weighted glass fiber. The cells, after being precipitated on the filter study, were washed twice with distilled water and dried overnight in an oven at $105^{\circ} \mathrm{C}$.

\section{Chlorophyll estimation}

Total chlorophyll contents were estimated in acetone extract according to Jeffrey \& Humphery(1975).

\section{Biochemical analysis}

Total protein was estimated by using the methods of Lowery et al. (1951). Total amino acid content was determined according to Moore \& Stein (1948). Total carbohydrate was estimated by Roe (1955) method.

Measurements of photosynthetic activity $\left(\mathrm{O}_{2}\right.$ evolution) and respiration $\left(\mathrm{O}_{2}\right.$ uptake)

The photosynthetic activity was measured polarographically as oxygen evolution using a Clark-type electrode (YSI, model53). The actinic white light was obtained from a $150 \mathrm{~W}$ tungsten lamp.

Measurements were carried out using of algal suspension at room temperature. Respiration was measured in dark as $\mathrm{O}_{2}$ uptake in the sample(ElNaggar et al., 1999).

\section{Statistical analysis}

All experiments were carried out in triplicate and the mean values with standard deviation are presented (mean \pm standard deviation(SD). The statistical analyses were carried out using SAS (v 612, SAS, Cary, NC). Data obtained were analyzed statistically to determine the degree of significance using one way analysis of variance (ANOVA, $\mathrm{P} \leq 0.05$ ). The inhibitory concentration of metal able to reduce the growth rate by $50 \%$ was calculated during the exponential growth at $72 \mathrm{~h}$ (IC50), by using linear interpolation method for sub-lethal toxicity using Probit analysis (Finney, 1971).

\section{Results}

Effect of copper and lead on the growth Toxicity

The effect of increasing copper and lead concentrations on the cell density of Spirulina platensis is shown in Fig. 1. The exposure of Spirulina platensis for $72 \mathrm{~h}$ to different concentrations of $\mathrm{Cu}^{2+}$ and $\mathrm{Pb}^{2+}(0,0.5,1$ and 3 $\mathrm{mg} / \mathrm{L})$ showed that an exponential negative relationship between algal dry weight and the amount of metal supplied to the medium. The decrease in the cell density with increasing of metal concentration was most pronounced with $\mathrm{Cu}^{2+}$ followed by $\mathrm{Pb}^{2+}$. Moreover the (IC50) values calculated are 0.54 and 0.62 for $\mathrm{Cu}^{2}$ and $\mathrm{Pb}^{2+}$, respectively. Culture treated with $\mathrm{Cu}^{2+}$ or $\mathrm{Pb}^{2+}$ at different concentrations ( 1 and $3 \mathrm{mg} / \mathrm{L}$ ) led to insignificant in biomass productivity of Spirulina platensis. On the other hand, at concentration 0.5 of $\mathrm{Cu}^{2+}$ or $\mathrm{Pb}^{2+}$ reveal that there was no significant effect on cell density.

\section{Growth curve}

The effect of copper and lead on the growth of Spirulina platensis are shownin Fig. 2. There was no significant effect under the $0.5 \mathrm{mg} / \mathrm{L}$ treatment of $\mathrm{Cu}^{2+}$ and $\mathrm{Pb}^{2+}$ in the medium. The growth of Spirulina platensis gradually increased in the culture supplemented by $0.5 \mathrm{mg} / \mathrm{L}$ of $\mathrm{Cu}^{2+}$ and $\mathrm{Pb}^{2+}$ during exposure periods. Whereas other concentrations of the two metals ( 1 and $3 \mathrm{mg} / \mathrm{L}$ ) cause a clear reduction in the growth of Spirulina platensis. The dry weight of Spirulina platensis was lower than the control in all cases when exposure concentration increased to $3 \mathrm{mg} / \mathrm{L}$ indicating that specific concentration had an inhibiting impact on algal growth. The inhibition effect become weaker with increase of exposure time. $\mathrm{Cu}^{2+}$ caused more inhibition effect on the growth of Spirulina platensis than $\mathrm{Pb}^{2+}$. The growth curves of Spirulina platensis in Zarrouk medium, 0.5 and $1 \mathrm{mg} / \mathrm{L}$ of different metalsshowing the lag phase lasted about $48 \mathrm{~h}$, while the logarithmic growth 
started approximately after $48 \mathrm{~h}$ of inoculation and Continued to $12^{\text {th }}$ day. The stationary phase started from $12^{\text {th }}$ day and ended at the $20^{\text {th }}$ day.
While at concentration $3 \mathrm{mg} / \mathrm{L}$ of different metals, noticed the lag phase was extended to $4^{\text {th }}$ day, the exponential period was extended to $11^{\text {th }}$ day.

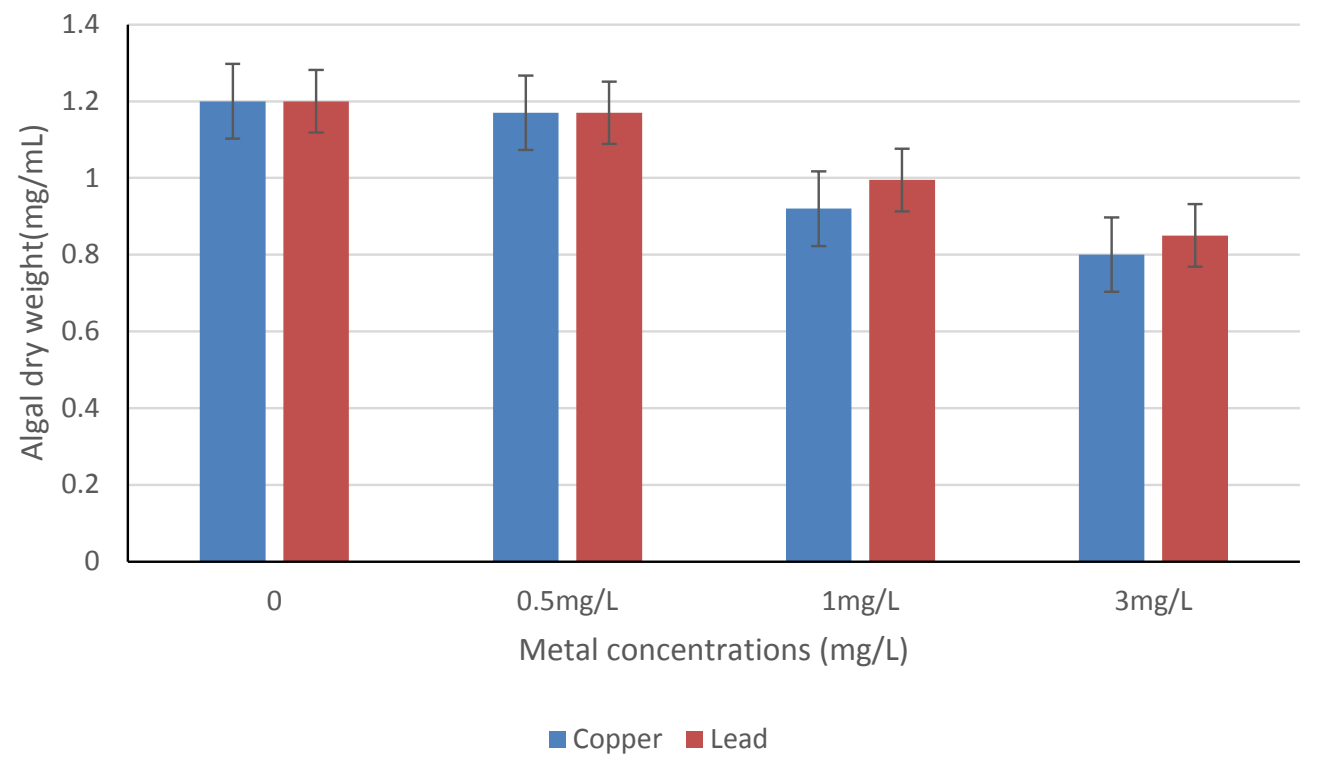

Fig. 1. Effect of various concentrations of copper and lead on the growth of Spirulina platensis after $72 \mathrm{~h}$ of exposure on Zarrouk medium (Data are means \pm SD). The effects of the treatments were tested by one-way analysis of variance (ANOVA). Means were compared between the treatments using the LSD (least significant difference) test at the 0.05 probability level.
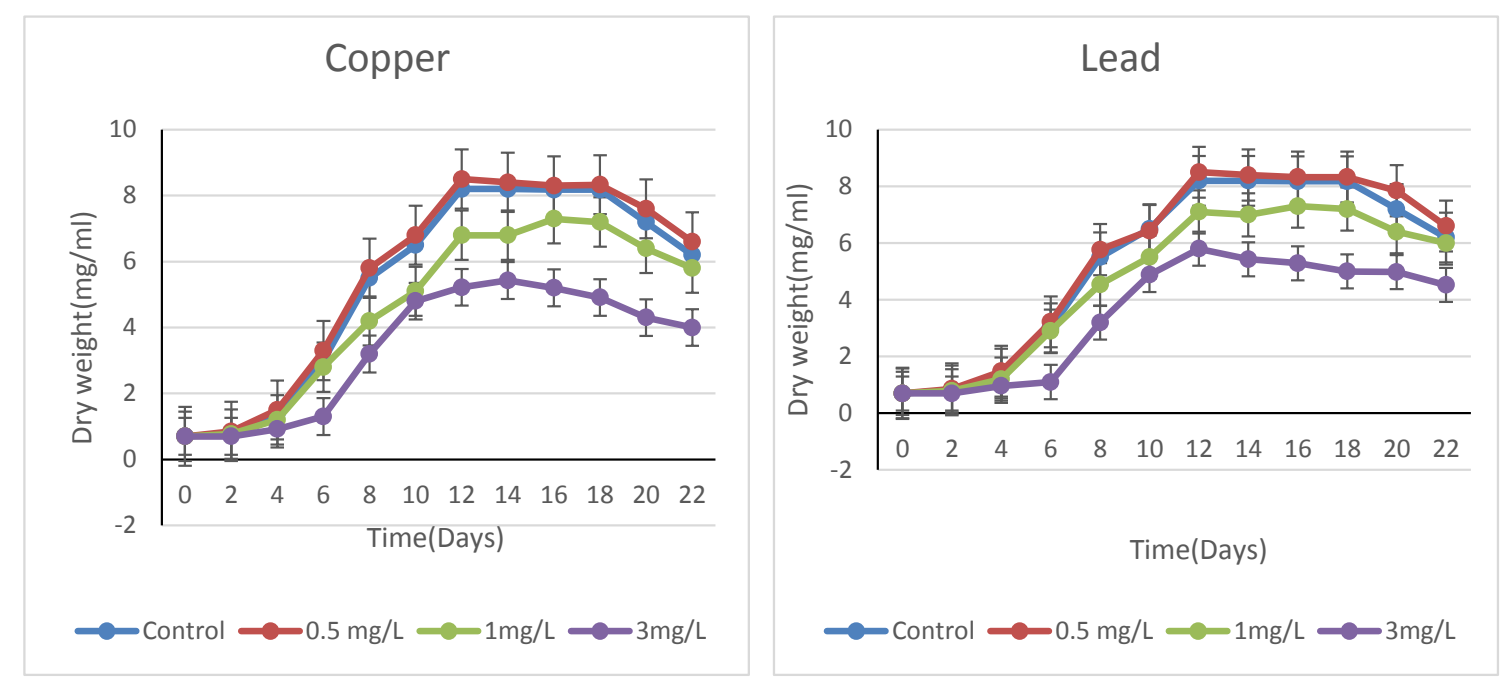

Fig. 2. Effect of various concentrations of copper and lead on the growth of Spirulina platensis after incubation period. (Data are means $\pm \mathrm{SD})(\mathrm{n}=3)$. The effects of the treatments were tested by one-way analysis of variance(ANOVA). Means were compared between the treatments using the LSD (least significant difference) test at the 0.05 probability level. 
Effect of $\mathrm{pH}$ on uptake of $\mathrm{Cu}^{2+}$ and $\mathrm{Pb}^{2+}$ by living and non-living biomass

Data presented in Fig. 3 A showed that the increase in the uptake of different metals was associated with the increasing of $\mathrm{pH}$ value of the medium. The uptake of $\mathrm{Pb}^{2+}$ metal by Spirulina platensis living biomass was higher than $\mathrm{Cu}^{2+}$. The maximum uptake of lead $(26.6 \mu \mathrm{g} / \mathrm{g})$ at $\mathrm{pH} 11$ and copper $(20.4 \mu \mathrm{g} / \mathrm{g})$ at $\mathrm{pH} 10.5$. The minimum uptake of both metals were recorded at $\mathrm{pH} 8.5$ and

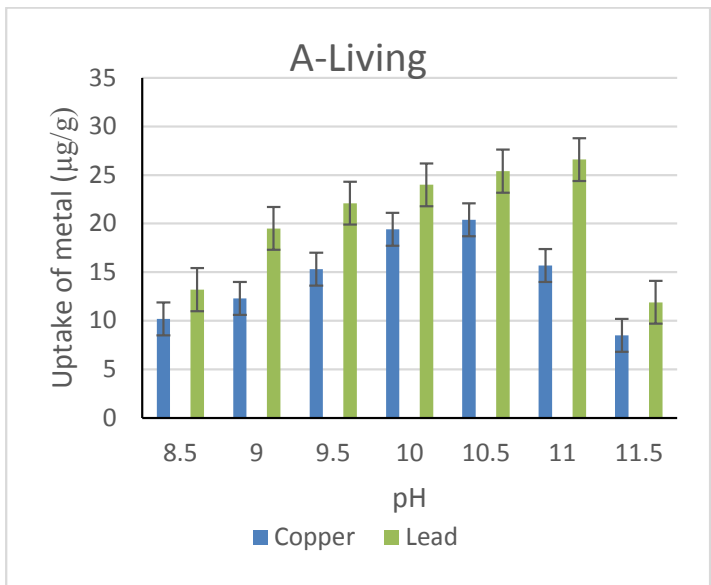

11.5, moreover, the growth of Spirulina platensis was inhibited in $\mathrm{pH}$ lower than 8.5 and higher than 11.5. The results showed an obvious effect of pH on uptake of $\mathrm{Cu}^{2+}$ and $\mathrm{Pb}^{2+}$ (Fig. 3 B) by nonliving biomass of Spirulina platensis. The two heavy metals had highest uptake at $\mathrm{pH} 7$, which was $(210 \mu \mathrm{g} / \mathrm{g})$ for $\mathrm{Cu}^{2+}$, and $(110 \mu \mathrm{g} / \mathrm{g})$ for $\mathrm{Pb}^{2+}$. The lowest uptake of $\mathrm{Cu}^{2+}$ and $\mathrm{Pb}^{2+}$ observed at $\mathrm{pH}$ 2 , at where the uptake was $50 \mu \mathrm{g} / \mathrm{g}$ for $\mathrm{Cu}^{2+}$ and $25 \mu \mathrm{g} / \mathrm{g}$ for $\mathrm{Pb}^{2+}$

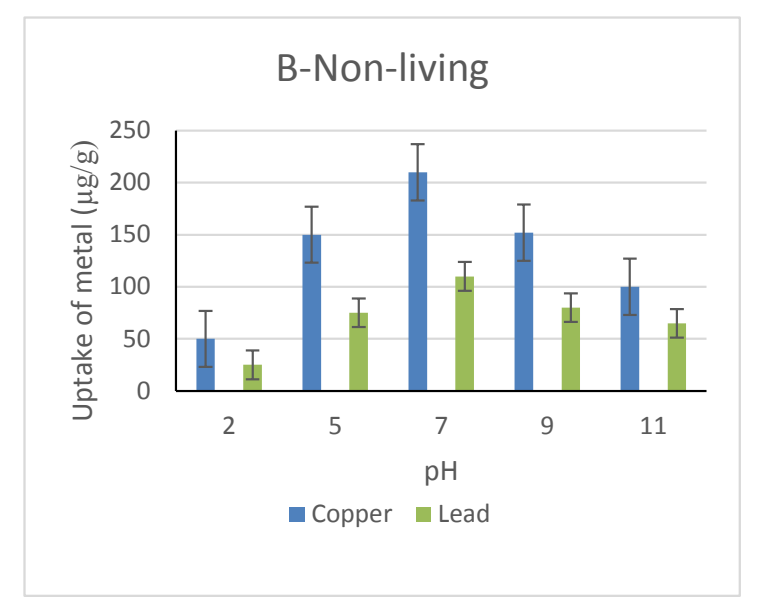

Fig. 3(A and B). Effect of pH on uptake of copper and lead by living and non-living biomass of Spirulina platensis. (Data are means $\pm \mathrm{SD})(\mathrm{n}=3)$.

Effect of the ion concentration on uptake of $\mathrm{Cu}^{2+}$ and $\mathrm{Pb}^{2+}$ by living biomass and non-living biomass

The data of Fig. 4 (A and B) performed that the metals accumulation of copper and lead by living and non-living Spirulina platensis were parallel to increasing the concentrations in the culture medium. Also, it can be seen that the tested alga Spirulina platensis accumulated an appreciable amount of lead more than other that observed with copper. It is known that the uptake of an element from surrounding medium is seldom exactly proportional to the amount present in the water. The highest uptake was for $\mathrm{Pb}^{2+}$. The effect of different concentrations of metals on biosorption process noticed that at low of both metal concentration, most of the heavy metals were almost completely removed by living and non-living Spirulina platensis.

\section{Effect of $\mathrm{Cu}^{2+}$ and $\mathrm{Pb}^{2+}$ on the total chlorophyll content}

As can be seen in Fig.5 (A), pigment content of Spirulina platensis decreased with increasing metal concentration. In contrast, inhibitions caused by $\mathrm{Cu}^{2+}$ were considerably higher than of $\mathrm{Pb}^{2+}$. Spirulina platensis exposed to $3 \mathrm{mg} / 1 \mathrm{~Pb}^{2+}$, resulted in $48.74 \%$ inhibition of chlorophyll.
While the inhibition caused by the same $\mathrm{Cu}^{2+}$ concentration was $65.9 \%$.

\section{Effect of $\mathrm{Cu}^{2+}$ and $\mathrm{Pb}^{2+}$ on the protein content}

The total protein content of Spirulina platensis showed reductions upon exposure to different concentrations $\mathrm{Cu}^{2+}$ and $\mathrm{Pb}^{2+}$ (Fig. 5B). The total protein content of the untreated sample (493.63 $\mathrm{mg} / \mathrm{L})$. At concentration $0.5 \mathrm{mg} / \mathrm{L}$ of copper and lead the total protein content reduced to $(459.63$ and $475.75 \mathrm{mg} / \mathrm{L})$, respectively. However, at $3 \mathrm{mg} / \mathrm{L}$ of copper and lead, the total protein decreased to (182.47 and $271.26 \mathrm{mg} / \mathrm{L})$, respectively. We noticed that the lowest effect on protein content was for $\mathrm{Pb}^{2+}$ whereas the highest was $\mathrm{Cu}^{2+}$.

Effect of $\mathrm{Cu}^{2+}$ and $\mathrm{Pb}^{2+}$ on total free amino acids

Figure (6A) clearly shows that the total free amino acids of Spirulina platensis gradually increased with increasing metals concentration. The most pronounced stimulation was detected at the culture supplemented with $3 \mathrm{mg} / \mathrm{L}$ copper in comparison to lead. On other hand lead also stimulated the biosynthesis of the total free amino acids, but the stimulatory effect is less than that obtained with copper. 

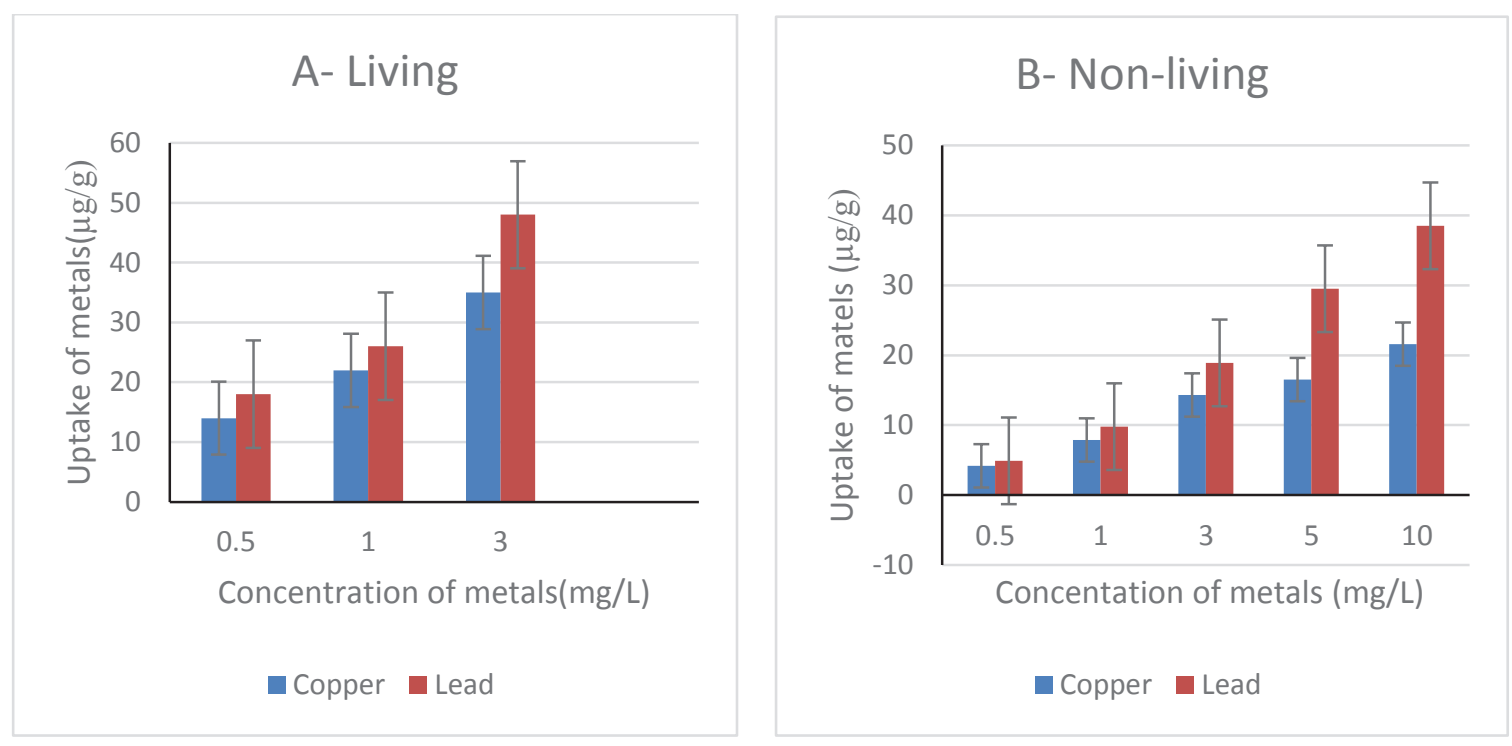

Fig. 4 (A and B). Effect of heavy metals concentration on the uptake of copper and lead by living and non-living biomass of Spirulina platensis. (Data are means $\pm \mathrm{SD})(\mathrm{n}=3)$.

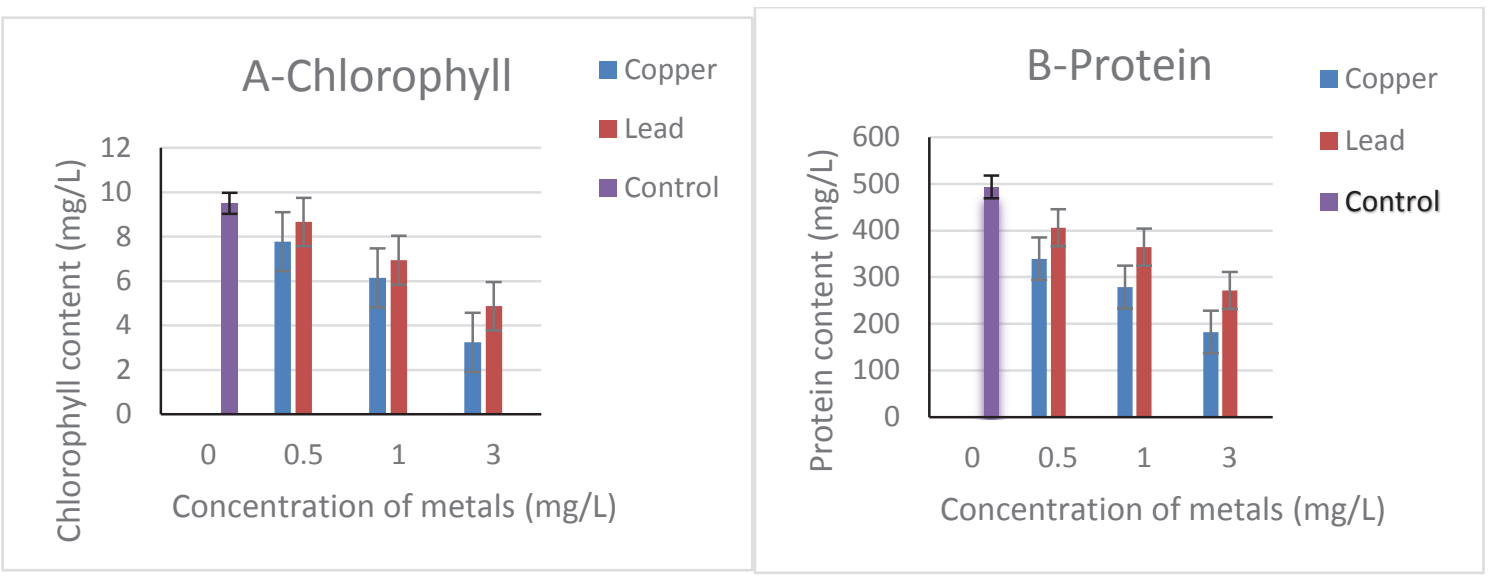

Fig. 5 (A and B). Effect of the concentration of copper and lead on Total chlorophyll content and protein content of Spirulina platensis. (Data are mean \pm SD) $(\mathbf{n}=3)$.

Effect of $\mathrm{Cu}^{2+}$ and $\mathrm{Pb}^{2+}$ on the total carbohydrate contents

The total carbohydrate contents of Spirulina platensis cultures grown 8 days under various concentrations of $\mathrm{Cu}^{2+}$ and $\mathrm{Pb}^{2+}$ were determined. Carbohydrate content of the tested alga also declined in manner dependent on the metal concentration exist in the medium. The results obtained in Fig. 6(B) shows that the two tested metals initiated the total carbohydrates accumulation at the culture supplemented by $1 \mathrm{mg} / \mathrm{L}$. It is worth to mention that high concentrations of the tested metals did not reduce the carbohydrates. 

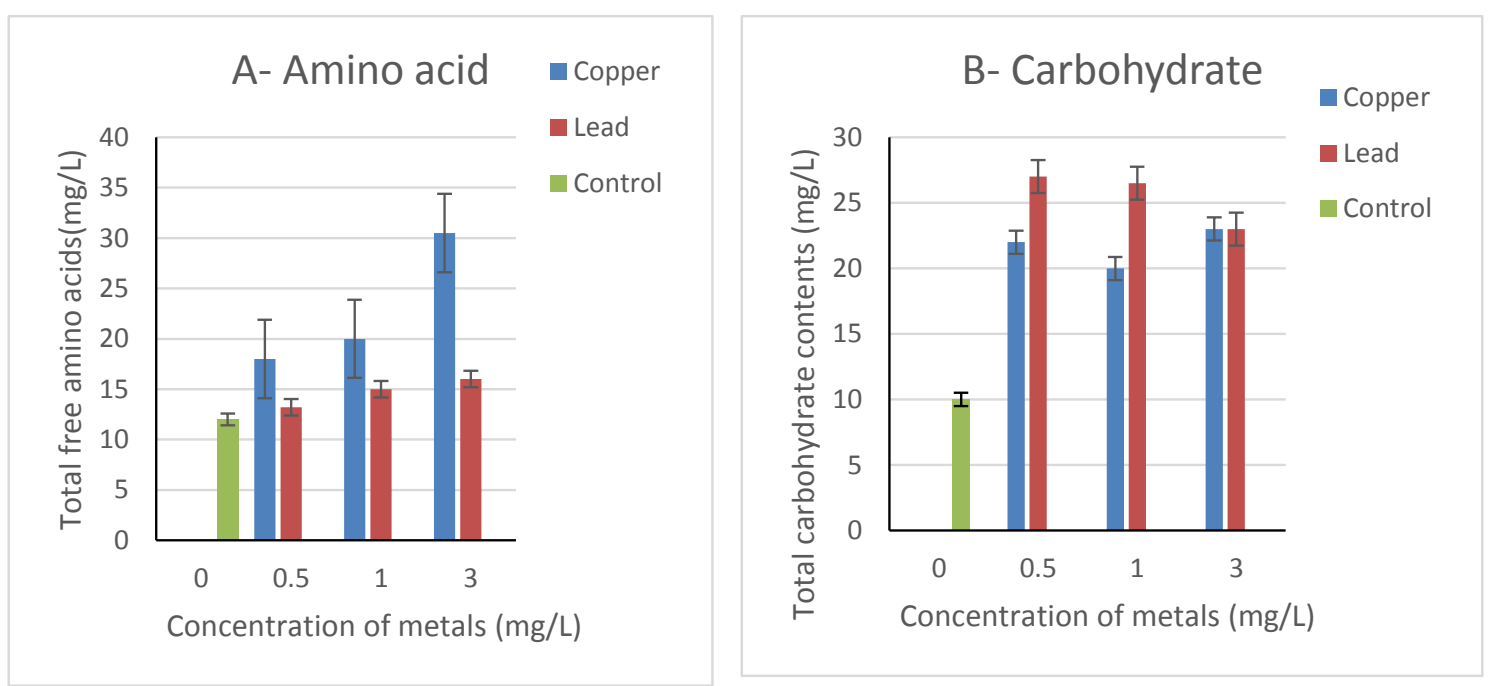

Fig. 6. Effect of the concentration of copper and lead on the total free amino acids (A) and carbohydrate contents (B) of Spirulina platensis. (Data are means \pm SD) $(n=3)$.

Effect of different concentrations of $\mathrm{Cu}^{2+}$ and $\mathrm{Pb}^{2+}$

\section{Discussion}

on the photosynthetic activity $\mathrm{O}_{2}$ evolution and respiration of Spirulina platensis

Data presented in Table 1 show that low concentrations of $\mathrm{Cu}^{2+}$ and $\mathrm{Pb}^{2+}(0.5 \mathrm{mg} / \mathrm{L})$ generally stimulated $\mathrm{O}_{2}$ evolution and dark respiration throughout the experimental period (10 days). The maximum $\mathrm{O}_{2}$ evolution (12.5\%) and dark respiration $(26.3 \%)$ were recorded on the $12^{\text {th }}$ and $8^{\text {th }}$ days, respectively for the cultures treated with $0.5 \mathrm{mg} / \mathrm{L}$ of $\mathrm{Cu}^{2+}$ in comparison with control. At the same concentration of both metal, the results reveal that there was significant effect on the $\mathrm{O}_{2}$ evolution and $\mathrm{O}_{2}$ uptake only with $\mathrm{Pb}^{2+}$. The results cleared that the rate of $\mathrm{O}_{2}$ evolution and $\mathrm{O}_{2}$ uptake increased under the effect of the two metals in concentration $(0.5 \mathrm{mg} / \mathrm{L})$. However, the photosynthetic activity of Spirulina platensis showed progressive reductions in response to treatment with higher $\mathrm{Cu}^{2+}$ and $\mathrm{Pb}^{2+}$ concentrations ( 1 and $3 \mathrm{mg} / \mathrm{L}$ ) during the cultivation period.

Data recorded in Table 1 also cleared that in case of $\mathrm{Pb}^{2+}$,the rate of $\mathrm{O}_{2}$ uptake of the culture increased gradually by increasing the concentration from 0.5 up to $1 \mathrm{mg} / \mathrm{L}$, while at the concentration $3 \mathrm{mg} /$ $\mathrm{L}, \mathrm{O}_{2}$ uptake decreased gradually with increasing the concentration of lead. On the contrary, $\mathrm{Cu}^{2+}$ caused gradual decrease in $\mathrm{O}_{2}$ uptake at all concentrations used at periods of culturing, where the maximum decreased was recorded at $12^{\text {th }}$ day at concentration 3 $\mathrm{mg} / \mathrm{L}$. However, cultures treated with (1 and $3 \mathrm{mg} / \mathrm{L}$ ) of $\mathrm{Cu}^{2+}$ and $\mathrm{Pb}^{2+}$ led to insignificant $\mathrm{O}_{2}$ evolution and $\mathrm{O}_{2}$ uptake except at $1 \mathrm{mg} / \mathrm{L}$ of $\mathrm{Pb}^{2+}$, the $\mathrm{O}_{2}$ uptake was significant in second and fourth day.

In recent years, heavy metal pollution has become one of the most serious environmental pollution. Presence of different heavy metals even in traces is toxic and detrimental to both flora and fauna. The use of biological materials in general and microalgae including cyanobacteria in particular, has received considerable attention during recent decades for removal of heavy metals as the environment friendly alternative technology (Romera et al., 2006). Growth inhibition in cyanobacteria is well known for metal toxicity and found to be related to the amount of meta bound to the algal cell surface in some cases, to the amount of intercellular metal and to the chemical nature of the metal (Priyadarshani \& Rath, 2012).

According to Toress et al. (1997) growth is a best parameter to determine the toxic action of the metals in microalgae and reflects the metabolic process in the cell. During the $72 \mathrm{~h}$ of experiment duration, the algal growth was inhibited due to increasing metal concentration. However Spirulina platensis were acutely sensitive to metals in a manner $\mathrm{Cu}^{2+}>\mathrm{Pb}^{2+}$. The present result was in agreement with those obtained by Yan \& Pan (2002), algal density was affected by these metals $(\mathrm{Cd}, \mathrm{Cu}$ and $\mathrm{Zn}$ ) but more tolerance was observed with $\mathrm{Cu}^{2+}$. The results in Fig. 1 indicated that the Spirulina platensis was most sensitive to $\mathrm{Cu}^{2+}$ at $0.54 \mathrm{mg} / \mathrm{L}$ followed by $\mathrm{Pb}^{2+}$ at $0.62 \mathrm{mg} / \mathrm{L}$. Although $\mathrm{Cu}^{2+}$ are essential metals for living organisms, this metal can be toxic and cause algal cell death at high concentrations. 
TABLE 1. Effect of different concentrations of $\mathrm{Pb}^{2+}$ and $\mathrm{Cu}^{2+}$ on the photosynthetic activity $\left(\mathrm{O}_{2}\right.$ evolution calculated as $\mu \mathrm{mol} \mathrm{O}_{2} \mathrm{mg}$ chlorophyll $\left.{ }^{-1} \mathrm{~h}^{-1}\right)$ and dark respiration $\left(\mathrm{O}_{2}\right.$ uptake calculated as $\left.\mu \mathrm{mol} \mathrm{O}_{2} \mathrm{~h}^{-1}\right)$ of Spirulina platensis. Each value is the mean of three reading \pm standard deviation(SD).

\begin{tabular}{|c|c|c|c|c|c|c|c|c|c|}
\hline \multirow[t]{2}{*}{ Days } & \multicolumn{2}{|l|}{ Control } & \multirow[t]{2}{*}{ Element } & \multicolumn{2}{|r|}{$0.5(\mathrm{mg} / \mathrm{L})$} & \multicolumn{2}{|r|}{$1(\mathrm{mg} / \mathrm{L})$} & \multicolumn{2}{|r|}{ 3(mg/L) } \\
\hline & $\mathrm{O}_{2}$ evol & $\mathrm{O}_{2}$ upt. & & $\mathrm{O}_{2} \mathrm{evol}$ & $\mathrm{O}_{2}$ upt. & $\mathrm{O}_{2} \mathrm{evol}$ & $\mathrm{O}_{2}$ upt. & $\mathrm{O}_{2}$ evol & $\mathrm{O}_{2}$ upt. \\
\hline \multirow[t]{2}{*}{2} & \multirow[t]{2}{*}{$432 \pm 0.1$} & \multirow[t]{2}{*}{$1.32 \pm 0.2$} & $\mathrm{Cu}^{2+}$ & $461 \pm 0.1 *$ & $1.24 \pm 0.4^{\mathrm{n}}$ & $302 \pm 0.1^{\mathrm{n}}$ & $1.22 \pm 0.1^{\mathrm{n}}$ & $264 \pm 0.1^{\mathrm{n}}$ & $0.95 \pm 0.1^{\mathrm{n}}$ \\
\hline & & & $\mathrm{Pb}^{2+}$ & $471 \pm 0.4^{*}$ & $1.63 \pm 0.1^{*}$ & $406 \pm 0.1^{n}$ & $1.47 \pm 0.4^{*}$ & $371 \pm 0.2^{\mathrm{n}}$ & $1.45 \pm 0.1 *$ \\
\hline \multirow[b]{2}{*}{4} & \multirow[t]{2}{*}{$322 \pm 0.1$} & \multirow[t]{2}{*}{$1.61 \pm 0.1$} & $\mathrm{Cu}^{2+}$ & $332 \pm 0.1 *$ & $1.22 \pm 0.3^{\mathrm{n}}$ & $230 \pm 0.1^{\mathrm{n}}$ & $1.21 \pm 0.1^{\mathrm{n}}$ & $201 \pm 0.7^{\mathrm{n}}$ & $1.01 \pm 0.1^{\mathrm{n}}$ \\
\hline & & & $\mathrm{Pb}^{2+}$ & $342 \pm 0.1 *$ & $1.83 \pm 0.3^{*}$ & $301 \pm 0.1^{\mathrm{n}}$ & $1.74 \pm 0.1^{*}$ & $251 \pm 0.5^{\mathrm{n}}$ & $1.42 \pm 0.1^{\mathrm{n}}$ \\
\hline \multirow[b]{2}{*}{8} & \multirow[b]{2}{*}{$220 \pm 0.1$} & \multirow[b]{2}{*}{$1.52 \pm 0.1$} & $\mathrm{Cu}^{2+}$ & $224 \pm 0.2^{*}$ & $1.22 \pm 0.1^{\mathrm{n}}$ & $164 \pm 0.1^{\mathrm{n}}$ & $1.20 \pm 0.3^{\mathrm{n}}$ & $150 \pm 0.1^{\mathrm{n}}$ & $0.95 \pm 0.1^{\mathrm{n}}$ \\
\hline & & & $\mathrm{Pb}^{2+}$ & $232 \pm 0.1 *$ & $1.68 \pm 0.1^{*}$ & $203 \pm 0.1^{\mathrm{n}}$ & $1.46 \pm 0.1^{\mathrm{n}}$ & $193 \pm 0.3^{n}$ & $1.04 \pm 0.3^{\mathrm{n}}$ \\
\hline \multirow[b]{2}{*}{12} & \multirow[b]{2}{*}{$162 \pm 0.2$} & \multirow[b]{2}{*}{$1.40 \pm 0.3$} & $\mathrm{Cu}^{2+}$ & $141 \pm 0.5^{\mathrm{n}}$ & $1.21 \pm 0.1^{\mathrm{n}}$ & $131 \pm 0.2^{\mathrm{n}}$ & $1.02 \pm 0.4^{\mathrm{n}}$ & $126 \pm 0.1^{\mathrm{n}}$ & $0.64 \pm 0.2^{\mathrm{n}}$ \\
\hline & & & $\mathrm{Pb}^{2+}$ & $171 \pm 0.1 *$ & $1.43 \pm 0.2 *$ & $160 \pm 0.1^{\mathrm{n}}$ & $1.35 \pm 0.1^{\mathrm{n}}$ & $145 \pm 0.1^{\mathrm{n}}$ & $0.99 \pm 0.2^{\mathrm{n}}$ \\
\hline
\end{tabular}

*Significant at $\mathrm{P} \leq 0.05$ using one way analysis of variance(ANOVA), ${ }^{\mathrm{n}}$ nonsignificant at $\mathrm{P} \leq 0.05$ using one way analysis of variance (ANOVA).

In general, changes in the biomass, total chlorophyll content or protein content are studied to assess the algal responses to metal exposure. Studing the effects of $\mathrm{Cu}^{2+}$ or $\mathrm{Pb}^{2+}$ on the filamentous cyanobacterium Spirulina platensis revealed that the toxicity for all the observed parameters including the growth was increased in a dose dependent manner. The results of this study showed a relative reduction in algal growth at higher concentrations of copper and lead. Such growth retardation is similar to that observed to Spirulina platensis (Choudhary et al., 2007) and Chlorella pyrenoidosa (Mohy El-din,2016).

Most reports demonstrated that the inhibitory effect of the stress become greater with an increase in the metal concentrations suggesting that the reduction of growth of algae was due to a decrease in photosynthesis occurred by the inhibition of chlorophyll synthesis. The mechanism proposed for the inhibition is the replacement of magnesium in the chlorophyll molecules, consequently cells accumulate protoporphyrin and synthesis of chlorophyll is blocked, this may be attributed to the inhibition of reduction step in the biosynthetic pathways of this pigment (Osman et al., 2004). The present results are in agreement with those obtained by Osman et al.(2004) who reported that high concentrations of $\mathrm{Co}^{2+}$ and $\mathrm{Ni}^{2+}$ decreased the chlorophyll a content in two algal species Scenedesmus obliquus and Nitzschia perminuta.

A decrease of protein content was detected in Spirulina platensis cells grown in media treated with $\mathrm{Cu}^{2+}$ and $\mathrm{Pb}^{2+}$ at concentration $3 \mathrm{mg} / \mathrm{Lby} 36.96$ and $54.95 \%$, respectively comparing of control. Probably, chlorophylls and proteins represented an emergency source of nitrogen, the reduction of protein content might also be attributed to the shortage of carbon skeleton resulting from low photosynthetic rate. Such results are in accordance with those of Carfagna et al. (2013). Generally, the accumulation of amino acids in response to metal concentrations may lead to the assumption that suppressed protein biosynthesis encouraged free amino acids accumulation, or may be due to some counteracting chelating mechanism against heavy metals toxicity (Fathi et al., 2005).

The $\mathrm{pH}$ obviously affected the uptake of $\mathrm{Cu}^{2+}$ and $\mathrm{Pb}^{2+}$ by Spirulina platensis living and nonliving biomass. The uptake by living biomass increased gradually by increasing $\mathrm{pH}$, until reached maximum uptake at specific $\mathrm{pH}$ points, after which the uptake declined. Maximum uptake by the living biomass occurred at $\mathrm{pH}$ points 10.5 for $\mathrm{Cu}^{2+}$ and 11 for $\mathrm{Pb}^{2+}$, while maximum uptake by non-living biomass occurred for two tested metals at pH 7. Chojnacka et al. (2005) reported that increasing of $\mathrm{pH}$-generally- activate more functional groups to involve in uptake process. The declining of uptake was caused probably by saturation of the binding sites, but increasing of $\mathrm{pH}$ might also change the ionic state of the metal, from ionic active form to stable (inactive) form, or to another active form but could not react with binding sites (Gupta et al., 2001). The present results revealed that the uptake of metals by 
living or non-living biomass dependent on the $\mathrm{pH}$ of medium, where, the uptake of metals by living biomass increased two times by increasing $\mathrm{pH}$ from 8.5 to 11 , then it was decreased by increasing $\mathrm{pH}$. However, the uptake by non-living biomass increased 4 times by increasing $\mathrm{pH}$ from 2 to 7 , then the uptake was decreased by increasing $\mathrm{pH}$. These results are in agreement with those obtained by Rangsayatorn et al. (2004) who reported the effect of $\mathrm{pH}$ on uptake of metals, the accumulation of cadmium by non-living suspensions of Spirulina platensis increased nearly 3-4 times by increasing $\mathrm{pH}$ from 4 to 7 , then the uptake was the same from pH 7 to 9. High differences in the uptake between the living and non-living biomass because of the following reasons. First, part of the uptake process was controlled by the living cells in the uptake by living biomass whereas the uptake by non-living biomass was not. These results are in agreement with those obtained by Gadd (2000). Second, the binding sites in living biomass located mainly at the outer structures of the cell such as the sheath and cell wall, while almost all cellular components contributed in uptake by non-living biomass (Beveridge \& Koval, 1981). Finally, the $\mathrm{pH}$ values for uptake by living biomass represented moderate-high alkalinity, while $\mathrm{pH}$ values for uptake by non-living biomass represented acidic-neutral-alkaline, and that caused significant differences of the bindingparticipated functional groups between uptake by living and non-living biomass (Gupta et al., 2000). In this study, lead uptake was the highest $(26.6 \mu \mathrm{g} / \mathrm{g})$ at $\mathrm{pH} 11$ and copper $(20.4 \mu \mathrm{g} / \mathrm{g})$ at $\mathrm{pH}$ 10.5. The same influence of metal on uptake was observed in the uptake by non-living biomass. The uptake at $\mathrm{pH} 2$ was the lowest for two metals, at which copper uptake was $(50 \mu \mathrm{g} / \mathrm{g})$ and lead $(25 \mu \mathrm{g} / \mathrm{g})$ the same order of $\mathrm{pH} 2$. Copper uptake by non-living biomassat $\mathrm{pH} 9$ was $(152 \mu \mathrm{g} / \mathrm{g})$ and lead $(80 \mu \mathrm{g} / \mathrm{g})$ which was less than the uptake at $\mathrm{pH}$ 7. Thus, increasing of $\mathrm{pH}$ over 7 had a little effect on copper and lead uptake by non-living biomass. In contrast, the uptake of $\mathrm{Cu}^{2+}$ and $\mathrm{Pb}^{2+}$ by non-living biomass was significantly affected by rising $\mathrm{pH}$. The same pattern of uptake by nonliving biomass in relation to $\mathrm{pH}$ was reported in a study conducted by Pavasant et al.(2005), on the green marine macro-alga Caulerpa leillifera.

In addition, the physiology itself may have an overall effect on the way in which the metal is accumulated in the cell. It was demonstrated that there are two phases in metal adsorption by microalgae: the first phase, not dependent on cellular metabolism, where metal binds to the cellular surface and the second, slower phase, dependent on metabolism, where metal is accumulated in the interior of the cell (MorenoGarrigo et al., 2000). Figure 4 shows the total amount of two metal element biosorbed by Spirulina. platensis as function of different metals concentrations in the medium after eight days of exposure. The higher $\mathrm{pb}^{2+}$ accumulated in the exposed Spirulina. platensis, could be due to induction of heavy metal peptides sequestration (phytochelatin) and detoxifying metals in vegetal cells. The ability of microalgae to accumulate metals from aqueous solution is well- documented (Mohy El-din, 2016).

Algae take metals up both passively and actively. Some metals, such $\mathrm{Pb}^{2+}$ and $\mathrm{Sr}^{2+}$, may be passively adsorbed by charged polysaccharides in cell wall and intercellular matrix (Osman et al., 2004). Other metals $\left(\mathrm{Zn}^{2+}\right.$ and $\left.\mathrm{Co}^{2+}\right)$ are taken up actively against large intracellular concentration gradients. Hamdy (2000) reported that metal uptake dependent on the type of biosorbant, with different accumulation affinities towards the tested elements and the amount of metal uptake increased steeply by increasing the weight of the biomass. Fathi et al. (2005) reported that the uptake of an element from the surrounding medium is seldom exactly proportional to the amount present in the water.

The observed changing with all the previously discussed alterations chlorophyll, protein contents, total free amino acids and carbohydrate contents and any abnormalities were resultedprobably- mainly from the effect of $\mathrm{Cu}^{2+}$ and $\mathrm{Pb}^{2+}$ on Spirulina platensis.

In the present study the effect of different concentrations of $\mathrm{Cu}^{2+}$ and $\mathrm{Pb}^{2+}$ on photosynthetic $\mathrm{O}_{2}$ evolution showed a tendency towards reducing the amount of $\mathrm{O}_{2}$ evolved by Spirulina platensis in response to metals. However, an increase in $\mathrm{O}_{2}$ evolution by Spirulina platensis was observed at relatively low metals concentrations throughout the incubation period. The magnitude of the inhibitory action was found to increase with higher metals concentrations.

At concentrations 1 and $3 \mathrm{mg} / \mathrm{L}$ of two metals the degree of inhibition of $\mathrm{O}_{2}$ evolution for Spirulina platensis was differ where the rate 
of $\mathrm{O}_{2}$ evolution more inhibited under the effect of $\mathrm{Cu}^{2+}$ metal than the $\mathrm{Pb}^{2+}$ metal, indicating that photosynthetic electron transport of Spirulina platensis is more sensitive to $\mathrm{Cu}^{2+}$ metal toxicity than $\mathrm{Pb}^{2+}$ metal toxicity. These results are in agreement with El- Naggar et al.(1999) who found that low $\mathrm{Co}^{2+}$ concentration increased both $\mathrm{O}_{2}$ evolution and dark respiration in two cyanobacterial species, Calothrix fusca and Nostoc muscorum, whereas higher concentrations were inhibitory. Further confirmation of our results can be found in the data of Carfagna et al.(2013) who reported that Chlorella, $\mathrm{Cd}^{2+}$ had a much higher effect than $\mathrm{Pb}^{2+}$ on physiological process as $\mathrm{O}_{2}$ evolution (photosynthesis) and $\mathrm{O}_{2}$ uptake (respiration).

With regard to the effects of various levels of $\mathrm{Cu}^{2+}$ and $\mathrm{Pb}^{2+}$ on respiration, the results obtained show that higher $\mathrm{Cu}^{2+}$ and $\mathrm{Pb}^{2+}$ concentrations have an inhibitory effect on $\mathrm{O}_{2}$ uptake by Spirulina platensis. Low $\mathrm{Pb}^{2+}$ concentrations stimulated $\mathrm{O}_{2}$ uptake of Spirulina platensis throughout the experimental period. With respect of different concentrations of $\mathrm{Cu}^{2+}$ caused inhibition of $\mathrm{O}_{2}$ uptake throughout the incubation period. From the above mentioned results, it is noteworthy that the effect of heavy metals on respiration is concentration, types of metal and the length of culturing period dependent.

\section{Conclusion}

This study focused on the biosorption of $\mathrm{Cu}^{2+}$ and $\mathrm{Pb}^{2+}$ by living and nonliving biomass of alga Spirulina platensis. The $\mathrm{pH}$ and concentration of heavy metals influenced the biosorption process. We can be also concluded that Spirulina platensis biomass could be used to remove $\mathrm{Cu}^{2+}$ and $\mathrm{Pb}^{2+}$ from waste waters effectively. Their high biosorption capacities towards heavy metals, low cost and abundant availability in nature are advantages in exploring this algal specie for practical application.

Our data suggest that the toxic effects of the two heavy metals resulted is exposuretimedependent. Furthermore, the exposure of the algae to $\mathrm{Cu}^{2+}$ or $\mathrm{Pb}^{2+}$ compromises the growth of Spirulina platensis. These two heavy metals provoke a strong inhibition in the content of chlorophyll and protein levels.

Acknowledgements:My sincere gratitude to Dr. Nadia Noaman, Professor at Faculty of Science in
Alexandria University for providing the nonliving Spirulina platensis and Dr. Haba Saad, Doctor at Oceanography and Fisheries in Alexandria (ARE) for providing the living Spirulina platensis.

\section{$\underline{\text { References }}$}

Andrade, L.R., Farina, M. and Amado, G. (2004) Effect of copper on Enteromorpha flexuosa in vitro. Ecotoxicol. Environ. Safe. 58, 117-125.

Bates, S.S., Tessier, A.P.G. and Buffle, J. (1982) Zinc adsorption and transport by Chlamydomonas variabilis and Scenedesmas subspicatus b grown in semi-continuous cultures. J. Physiol. 18, 521-529.

Beveridge, T. and Koval, S. (1981) Binding of metals to cell envelopes of Escherichia coli K-12. Appl. Environ. Microbiol. 42, 325-335.

Bing, H., Wu, Y., Liu, E. and Yang, X. (2013) Assessment of heavy metal enrichment and its human impact in lacustrine sediments from four lakes in the mid-low reaches of the Yangtze River, China. J. Environ. Sci. 25, 13001-1309.

Carfagna, S., Vona, V., Sorbo, S., Basile, A., Salbitani, G. and Lanza, N. . (2013) Physiological and morphological responses of lead or cadmium exposed Chlorella sorokiniana. Springer Plus. 2, 147-153.

Choudhary, M., Jetley, U.K., Khan, M.A., Zutshi, S. and Fatma, T. (2007) Effect of heavy metal stress on proline, malondialdehyde, and superoxide dismutase activity in the cyanobacterium Spirulina platensis-S 5 . Ecotoxicol. Environ. Saf. 66, 204-209.

Chojnacka, K., Chojnacki, A. and Gorecka, H. (2005) Biosorption of $\mathrm{Cr}^{3+}, \mathrm{Cd}^{2+}$ and $\mathrm{Cu}^{2+}$ ions by blue-green algae Spirulina sp.: Kinetics, equilibrium and the mechanism of the process. Chemosphere, 59, 75-84.

El-Naggar, A.H., Osman, M.E.H., Dyab, M.A. and El-Mohsenawy, E.A. (1999) Cobalt and Lead toxicities on Calothrix fusca and Nostoc muscorum . J. Union Arab Biol. Cairo.7, 421-441.

Fathi, A.A., Ibraheim, H.A. and Zaki, F.T. (2005) Response of tolerant and wild type strains of Chlorella vulgaris to Copper with 
special references to Copper uptake system. Protisology, 4, 73-78.

Finney, D.J. (1971) "Probit Analysis". $3^{\text {rd }}$ ed. Combrige Press, New York, Ny.668pp.

Gadd, G. (2000) Bioremedial potential of microbial mechanisms of metal mobilization and immobilization. Curr. Opini. Biotechnol. 11, 271-279.

Gaetke, M. and Chow, C.K. (2003) Copper toxicity, oxidative stress and antioxidant nutrients. Toxicology, 189,147-163.

Gupta, R., Ahuja, P., Khan, S., Saxena, R. and Mohapatra, H. (2000) Microbial biosorbents: meeting challenges of heavy metal pollution in aqueous solutions. Curr. Sci. 78, 967- 973.

Gupta, V., Shrivastava, A. and Jain, N. (2001) Biosorption of chromium (VI) from aqueous solutions by green algae Spirogyra species. Wat. Res. 35, 4079-4085.

Hamdy, A.A. (2000) Biosorption of heavy metals by marine algae. Curr. Microbiol. 41, 232-238.

Henick-Kling, T. and Stoewasnd, G. (1993) Lead in wine. Amer. J. Enolo. Viticul. 44, 459-463.

Jeffrey, S.W. and Humphery, G. F. (1975) New spectrophotometric equations for determining chlorophyll a, b and c in higher plants, algae and natural populations. Biochem. Physiol. Pflanzen. 167, 185-199.

Lowery, O.H., Rosenbroug, N.J. Farr, A.F. and Randall, R.J. (1951) Protein measurement with the folin phenol reagent. J. Biol. Chem. 193, 265-275.

Mohy El-din, M.S. (2016) Effects of heavy metals (Copper, Cobaltand Lead) on the growth and photosynthetic pigments ofthe green alga Chlorella pyrenoidosa. CATRINA 15(1),1- 10.

Moore, S. and Stein, W. (1948) Photometric ninhydrine method for use in the chromatography of amino acids. J. Biol. Chem. 17, 367-388.

Moreno-Garrigo, I.., Lubian, L.M. and Soares, A.A. (2000) Influence of cellular density on determination of $\mathrm{EC}_{50}$ in microalgal growth inhibition tests.Chemospher, 47, 112-116.

Murugan, K. and Harish, S. (2007) Antioxidant modulation in response to heavy metal induced oxidative stress in Cladophera glomerata. Indian Journal of Eexperi. Bio. 45, 980-983.

Osman, M.E.H., El-Sheekh, M.M., El-Naggar, A.H. and El-Mazaly, E. (2004) Differential effects of $\mathrm{CO}^{2+}$ and $\mathrm{Ni}^{2+}$ on protein metabolism in Scenedesmus obliquus and Nitzschia perminuta. Enviro. Toxicol. Pharmacol. 16, 168-178.

Pavasant, P., Apiratikul, R., Sungkhum, V., Suthiparinyanont, P., Wattanachira, S. and Marhaba, T. (2005) Biosorption of $\mathrm{Cu}^{2+}$, $\mathrm{Cd}^{2+}, \mathrm{Pb}^{2+}$ and $\mathrm{Zn}^{2+}$ using dried marine green macroalga Caulerpa lentillifera. Biores. Technol. Article in press.

Penuelas, J. and Filella, I., (2002) Metal pollution in Spanish terrestrial ecosystems during the twentieth century. Chemosphere, 46, 501-505.

Priyadarshani, I., Rath, B. (2012) Effect of heavy metals on cyanobacteria of Odisha Coast. $J$. Micro. Biotechno. Res. 2, 665-674.

Rangsayatorn, N., Pokethitiyook, P., Upatham, E. and Lanza, G. (2004) Cadmium biosorption by cells of S. platensis TISTR 8217 immobilized in alginate and silica gel. Envi. Internat. 30, 57-63.

Romera, E., Gonzalez, F., Ballester, A. and Blazquez, M.L. (2006) Bisorption of as statistical re Crit. Rev. Biotechnol. 20, 223-235.

Roe, J.H. (1955) The determination of sugar in blood and spinal fluid with anthrone reagent. J. Biol. Chem .212, 335-343.

Sanita-di- Toppi, L.S. and Gabbrielli, R. (1999) Response to cadmium in higher plants. Environ. Exp. Bot. 41, 105-130.

Schutzendubel, A. and Polle (2002) Plant responses to abiotic stresses: heavy metalinduced oxidative stress and protection by mycorrhization. J. Exp. Bot. 53, 1351-1365.

Toress, E., Cid, A., Fidalgo, P., Herrero, C. and Abalde, J. (1997) Long chain class III 
metallothioneins as a mechanism of cadmium tolerance in marine diatom Phaeodactylum tricornutum Bohlin. Aquatic Toxicol. 39, 231.

Volesky, B. (1994) Advances in biosorption of metals: selection of biomass types. FEMS Microbiol. Rev.14, 291-302.

Volesky, B. and Holan, Z.R. (1995) Biosorption of heavy metals. Biotechnol. Progr. 11, 235-250.
Vonshak, A. (1997) Preface. In: "Spirulina platensis (Arthrospira): Physiology, Cellbiology and Biotechnology". Vonshak A. [Ed.], pp.: ix-x. $1^{\text {st }}$ ed. Taylor and Francis Ltd. London.

Yan, C.K. and Pan, G. (2002) Toxicity and bioaccumulation of copper in three microalgal species. Chemosphere, 49, 471.

Wang, T.C., Weissman, J.C. Ramesh, G. and Benemann, J.R. (1998) Heavy metal binding and removal by Phormidium. Bull. Environ. Contam. Toxicol. 60, 739-744.

\section{تاثير النحاس والرصاص على النمو وبعض الانشطة الايضية لطحلب الاسبيرولينا}

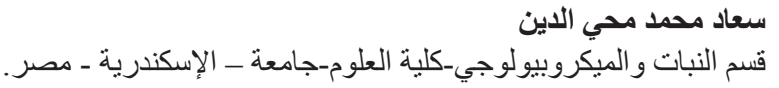

تعد مشكلة التلوث بالمعادن التقبلة اليوم واحدة من اهم المشكلات البيئية التي تسبب سلسلة من المعوقات في

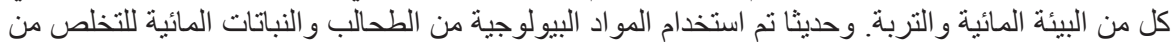

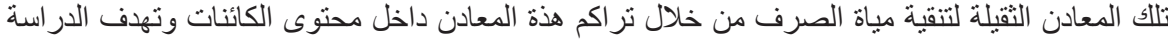

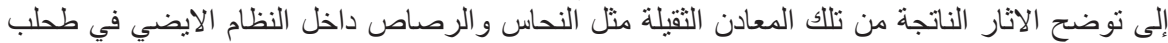

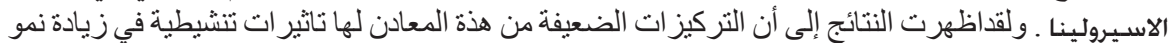

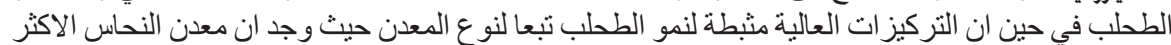

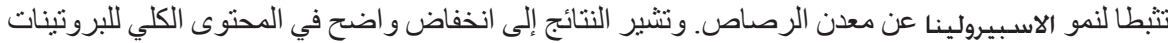

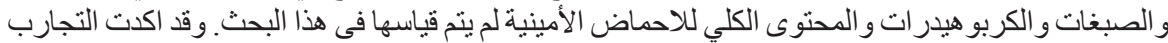

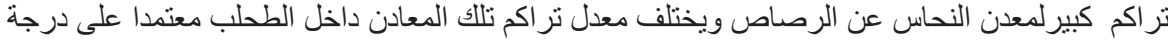

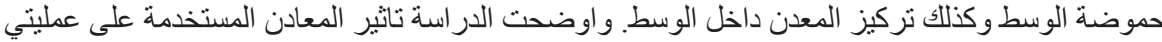
التنفس و البناء الضوئي حيث شو هد انخفاض في معدل الأكسجين الممتص في التركيز ات العالية التية للمعادن. 